\title{
A Slowly Inactivating Potassium Current Truncates Spike Activity in Ganglion Cells of the Tiger Salamander Retina
}

\author{
Peter Lukasiewicz and Frank Werblin \\ Neurobiology Group, University of California, Berkeley, California 94720
}

\begin{abstract}
Voltage-gated ganglion cell membrane currents were studied under whole-cell patch clamp in isolation and in retinal slices. The cells were identified by (1) backfilling their axons with rhodamine and later identifying them by their fluorescence in the slice or the mix of isolated cells or (2) by filling them with Lucifer yellow during recording in retinal slices. Both methods yielded cells with similar currents. In some cases, isolated cells lacked processes yet showed currents similar to other cells, suggesting that voltage-gated currents in all cells were located primarily at the soma. Both a conventional inactivating sodium current and a sustained calcium current were found.
\end{abstract}

We describe 3 inactivating outward currents, ordered in their rate of inactivation. The fastest current resembled $I_{A}$ reported by Connor and Stevens (1971 a, b). A slower current labeled $I_{B}$ inactivated with a time constant of $339 \mathrm{msec}$ at 0 $\mathrm{mV}$. The current with slowest inactivation is labeled $\mathrm{I}_{\mathrm{c}}$ here, inactivating with a time constant of $4.03 \mathrm{sec}$ at $0 \mathrm{mV}$. An additional outward current was sustained and calcium dependent, labeled $I_{\text {K(Ca) }}$.

$I_{B}$ was the largest of these currents. It was slower than $I_{A}$, was not blocked by 4AP, and inactivated over a much more positive potential range. $I_{B}$ appears to play an important role in spike generation, different from that of $I_{A}$ : Its inactivation leads to a slow depolarizing shift of the membrane during a current step, truncating spike activity after about 300-700 msec as the membrane potential enters the region of sodium inactivation. We analyze how the inactivating outward current acts to ensure a graded spiking response and to truncate the spiking output in the presence of large excitatory inputs.

The modulation of spiking in ganglion cells is controlled by the interaction of synaptic and voltage-gated currents. In lower vertebrates, various synaptic inputs converge upon ganglion cells to mediate different forms of response (Miller and Dacheux, 1976; Baylor and Fettiplace, 1979; Wunk and Werblin, 1979; Belgum et al., 1982, 1983). Little is known about the role of voltage-gated currents in the ganglion cell membrane in modulating spike activity. Baylor and Fettiplace (1979) showed that in turtle the ganglion cell membrane voltage and spike frequency were linear with input current over a major part of the physiological range. However, since recent patch recordings indicate

Received June 3, 1987; revised Mar. 14, 1988; accepted Mar. 25, 1988.

We thank Scott Eliasof for his help with the data analysis. This work was supported by NIH Grants EY-00561 (F.W.) and F32-EY05751 (P.L.).

Correspondence should be addressed to Frank Werblin at the above address.

Copyright (C) 1988 Society for Neuroscience 0270-6474/88/124470-12\$02.00/0 a significantly higher input resistance in ganglion cells, the leak caused by conventional intracellular electrodes might have shunted the membrane in those measurements so that nonlinear events mediated by voltage-gated currents could have gone unnoticed.

We have studied the voltage-gated ganglion cell currents, both in isolated cells and in retinal slices, to determine the nature of the interactions that might modulate spike activity. Most currents were quite conventional and similar to those described by Lipton and Tauck (1987) in isolated rat ganglion cells. A large, slowly inactivating outward current appears to control the magnitude and duration of spiking. Preliminary reports have appeared elsewhere (Lukasiewicz and Werblin, 1985, 1986).

\section{Materials and Methods}

Preparation. Whole-cell patch recordings (Hamill et al., 1981) were made from ganglion cells in the retinal slice and in isolated cells. Retinal slices were prepared using procedures described by Werblin (1978). Briefly, the vitreal side of a small piece of retina was placed against a Millipore filter. The sclera was then pulled away, leaving the retina adhering to the filter. The filter and retina were then sliced with a razorblade at $150 \mu \mathrm{m}$ intervals and positioned so that all the cells spanning the sliced edge could be viewed under a Zeiss $40 \times$ water-immersion objective. The slices were held in place by embedding the ends of the Millipore filter, which extended well beyond the retina, in Vaseline.

Isolated cells were prepared using the methods of Firestein and Werblin (1987). Briefly, retinas were isolated and incubated in a Ringer solution containing $1 \mathrm{mg} / \mathrm{ml}$ papain (Sigma, St. Louis) and $0.5 \mathrm{mg} / \mathrm{ml}$ $\mathrm{N}$-acetyl-L-cysteine (Sigma) for $30 \mathrm{~min}$ at $30^{\circ} \mathrm{C}$. The tissue was transferred to a $5 \%$ bovine serum solution for $10 \mathrm{~min}$ to quench residual papain activity. After several washes in Ringer, the digested retinas were gently triturated with pasteur pipettes to isolate the cells.

Cell identification. Cells in the slice and in isolation were visualized using Hoffman modulation contrast optics (Modulation Optics, Inc., Greenvale, NY). Ganglion cells were identified, using Lucifer yellow (Stewart, 1978), by the characteristic ramification of their processes within the inner plexiform layer and by the presence of axons.

Isolated cells were identified after being backfilled with rhodamine. Initially, several crystals of tetramethylrhodamine isothiocyanate, isomer R (RITC) (Sigma) were applied, after decapitation, to the distal end of the optic nerve. Following incubation of the head for 18-24 hr at $5^{\circ} \mathrm{C}$, cells were isolated as described above (Preparation). Cells that were fluorescent in the isolated mix were taken to be ganglion cells. In slice preparations prepared after the same incubation, almost all cells in the ganglion cell layer and virtually no cells in other layers were fluorescent (see Fig. 1). On rare occasions a singular cell, most likely a displaced ganglion cell, was stained in the inner nuclear layer. This shows that there was no significant leakage of rhodamine between adjacent cells.

Bathing solutions. Amphibian Ringer, pH 7.7-7.8, bathed the slices or isolated cells; the composition of this and the other solutions used to perfuse the slice are listed in Table 1 . In some cases excessive spontaneous inhibitory activity was encountered, requiring that strychnine and picrotoxin $(50 \mu \mathrm{M})$ be added to the bathing media to block this activity. No cells used in the figures shown here had such spontaneous activity. Tetrodotoxin (TTX; $0.3-1 \mu \mathrm{M}$ ) was added directly to the bathing solutions without substitution. 
Table 1. Composition of bathing solutions (in mM)

\begin{tabular}{|c|c|c|c|c|c|}
\hline Component & $\begin{array}{l}\text { A } \\
\text { Control }\end{array}$ & $\begin{array}{l}\text { B } \\
\text { Sodium } \\
\text { isolation }\end{array}$ & $\begin{array}{l}\mathrm{C} \\
\mathbf{I}_{(\mathrm{Ca})} / \mathrm{I}_{(\mathrm{K})} \\
\text { isolation }\end{array}$ & $\begin{array}{l}\mathrm{D} \\
\mathrm{I}_{\mathrm{B}} / \mathrm{I}_{\mathrm{C}} \\
\text { isolation }\end{array}$ & $\begin{array}{l}E \\
I_{A} \\
\text { isolation }\end{array}$ \\
\hline $\mathrm{NaCl}$ & 120 & 120 & 120 & 120 & 100 \\
\hline TEA & 0 & 0 & 0 & 0 & 20 \\
\hline $\mathrm{KCl}$ & 2 & 2 & 2 & 2 & 2 \\
\hline $\mathrm{CaCl}_{2}$ & 4 & 0 & 4 & 0 & 0 \\
\hline $\mathrm{CoCl}_{2}$ & 0 & 2 & 0 & 2 & 2 \\
\hline Glucose & 3 & 3 & 3 & 3 & 3 \\
\hline HEPES & 5 & 5 & 5 & 5 & 5 \\
\hline TTX & 0 & 0 & 0.001 & 0.001 & 0.001 \\
\hline
\end{tabular}

The solution bathing the slice was changed using a multichannel perfusion pump. The volume of the experimental chamber was $1 \mathrm{ml}$, and the flow rate was $0.2-0.4 \mathrm{ml} / \mathrm{min}$, so the bulk of the solution could be exchanged in about $2 \mathrm{~min}$. Solutions were introduced through a pipette with $5 \mu \mathrm{m}$ tip diameter placed near the slice so the solution around the slice was exchanged first.

Electrode solutions. Potassium or cesium and TEA were the predominant cations contained in the patch electrode solutions. The complete composition of the solutions contained in the electrodes is listed in Table 2 . In about $25 \%$ of the work, $2 \mathrm{mM} \mathrm{Mg}^{2+}$ was added to the electrode solution and $\mathrm{Ca}^{2+}$ concentration was reduced to $10^{-9} \mathrm{M}$. Experiments were performed at room temperature $\left(20-24^{\circ} \mathrm{C}\right)$.

Liquid junction potential correction. Liquid junction potentials were determined by first placing the electrodes in a bath containing the electrode solution to establish a zcro offset potential. Then, we measured the offset from the zero potential in normal bathing media. The offset was $3 \mathrm{mV}$ at $120 \mathrm{mM} \mathrm{Cl}^{-}$and $96 \mathrm{mM} \mathrm{Cs}^{+} / 20 \mathrm{mM} \mathrm{TEA}^{+}, 4 \mathrm{mV}$ at 120 $\mathrm{mM} \mathrm{Cl}^{-}$and $116 \mathrm{mM} \mathrm{K}^{+}$. Membrane potential values in this paper are corrected for these junction potentials.

Electrical constants of the membrane. Measurements for determining membrane resistance, capacitance, and resting level are shown in Figure 2. Figure $2 A$ shows a voltage response to a $10 \mathrm{pA}$ depolarizing current. The potential change evoked did not activate any voltage-gated currents (see below). The charging curve has a time constant of $20.0 \mathrm{msec}$. The plateau potential is $13.4 \mathrm{mV}$, so the membrane capacitance is $15.1 \mathrm{pF}$. We consistently measured input resistances averaging about $3 \mathrm{G} \Omega$, nearly an order of magnitude larger than previously reported using intracellular recording (Werblin, 1977; Baylor and Fettiplace, 1979). In some cells, the resting potential was initially around $-40 \mathrm{mV}$ but became more negative during the experiment, reaching a steady value similar to that derived from intracellular recording (mean, $-67.5 \mathrm{mV}, 41$ cells). Statistics from all such measurements are summarized in Table 3.

Ganglion cells can have extensive dendritic fields extending up to 200 $\mu \mathrm{m}$ from the cell body. The inability to adequately space-clamp such cells may introduce errors in the magnitude and kinetics of our measurements. Studies with enzymatically dissociated cells, often without any processes, showed similar currents, suggesting that the majority of the voltage-gated channels are located on or near the soma. The sodium channels mediating spike activity in ganglion cells are probably also located near the cell soma (Wollner and Catterall, 1986).

Series resistance. We used the membrane capacitance of $15 \mathrm{pF}$ (Fig. $2 A)$ and the time constant of the charging curve under voltage clamp in Figure $2 B$ to determine the value of the series resistance. The time constant for the charging curve in Figure $2 B$ was $0.15 \mathrm{msec}$, giving a series resistance of about $10 \mathrm{M} \Omega$. For the largest currents we measured here, near $1 \mathrm{nA}$, this series resistance would give an error of about 10 $\mathrm{mV}$. Most currents were smaller, so the errors in amplitude and kinetics due to the series resistance will be small

Recording system. Patch electrodes of 3-7 M resistance in Ringer were made on a David Kopf electrode puller (David Kopf, Coalinga, CA) using borosilicate glass (TW150-4, WPI Instruments, New Haven, CT). A List L/M-EPC7 patch clamp (Medical Systems Corp., Greenvale, NY) was used to voltage-clamp and/or current-clamp ganglion cells. Filtering was at $3 \mathrm{kHz}$. Sampling rate was either 1 or $6.7 \mathrm{kHz}$, depending upon the length of the record. The responses and stimuli were digitized by a Data Translations DT2801 analog-to-digital interface and recorded on an IBM PC/XT. Preprogrammed stimuli were delivered to the command input of the patch clamp using a digital-to-analog interface.

\section{Results}

Whole-cell currents. Figure $3 A$ shows a series of representative currents elicited from an isolated ganglion cell held at $-75 \mathrm{mV}$ and depolarized in $5 \mathrm{mV}$ steps. A transient inward current was activated at potentials positive to $-40 \mathrm{mV}$ and reached a maximum value of $1.2 \mathrm{nA}$ at a step to $-15 \mathrm{mV}$. A sustained outward current was activated at step potentials positive to $-40 \mathrm{mV}$ and reached a magnitude of $380 \mathrm{pA}$ at $-15 \mathrm{mV}$. Similar results were obtained from 14 other cells (see Table 3 ).

The responses to hyperpolarizing voltage steps are shown in Figure $3 B$. We found no evidence for voltage-gated currents at potentials more negative than the resting level of the cell, yet horizontal cells (Lasater, 1986) and bipolar cells (Kaneko and Tachibana, 1985) appear to have these currents. The inset in Figure $3 B$ shows that over the voltage range from -80 to -150 $\mathrm{mV}$ the cell had a linear conductance of $0.9 \mathrm{nS}$, or an input resistance of $1.1 \mathrm{G} \Omega$. Table 3 shows the range of input resistances for all cclls studicd.

Activation of transient inward current. A transient inward current was measured in isolation by blocking the outward currents with $96 \mathrm{~mm}$ cesium and $20 \mathrm{~mm}$ TEA in the recording electrode and blocking calcium current with $2 \mathrm{~mm}$ cobalt replacing calcium in the bathing medium (Weakly, 1973). Twenty-one cells were studied in this way with consistent results. Figure $4 A$ shows a series of selected inward currents elicited when the cell was held at $-75 \mathrm{mV}$ and depolarized to the indicated potentials.

The current-voltage relation for the complete set of transient inward currents, measured at the response peak, is shown in Figure $4 B$. The current began to activate at potentials more positive than $-40 \mathrm{mV}$ and reached a maximum of $739 \mathrm{pA}$ near

Table 2. Composition of electrode solutions (in mM)

\begin{tabular}{lllcc} 
Component & $\begin{array}{l}\text { A } \\
\text { Control } \\
\left(10^{-7} \mathbf{M C a}\right)\end{array}$ & $\begin{array}{l}\text { B } \\
\text { Control } \\
\left(10^{-9} \mathbf{M} \mathrm{Ca}\right)\end{array}$ & $\begin{array}{l}\mathrm{C} \\
\mathrm{I}_{(\mathrm{K})} \text { blockade } \\
\left(10^{-7} \mathbf{M ~ C a}\right)\end{array}$ & $\begin{array}{l}\text { D } \\
\mathrm{I}_{(\mathrm{K})} \text { blockade } \\
\left(10^{-9} \mathbf{M} \mathrm{Ca}\right)\end{array}$ \\
\hline $\mathrm{KCl}$ & 116 & 116 & 0 & 0 \\
$\mathrm{CsCl}$ & 0 & 0 & 96 & 96 \\
TEA-Cl & 0 & 0 & 20 & 20 \\
EGTA & 2 & 10 & 2 & 10 \\
$\mathrm{HEPES}$ & 4 & 4 & 4 & 4 \\
$\mathrm{MgCl}_{2}$ & 0 & 2 & 0 & 2 \\
$\mathrm{CaCl}_{2}$ & 1.6 & 0.08 & 1.6 & 0.08 \\
\hline
\end{tabular}




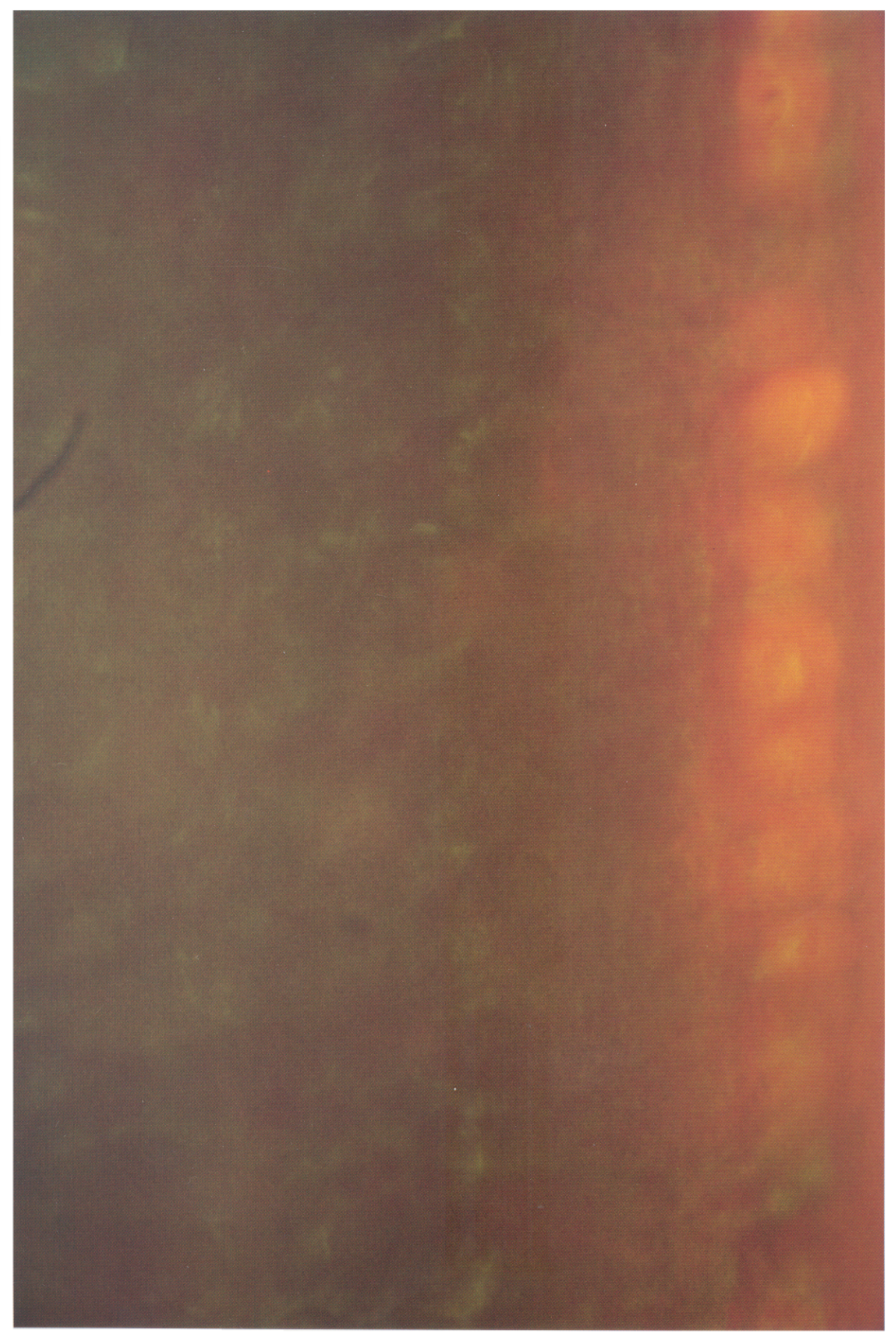




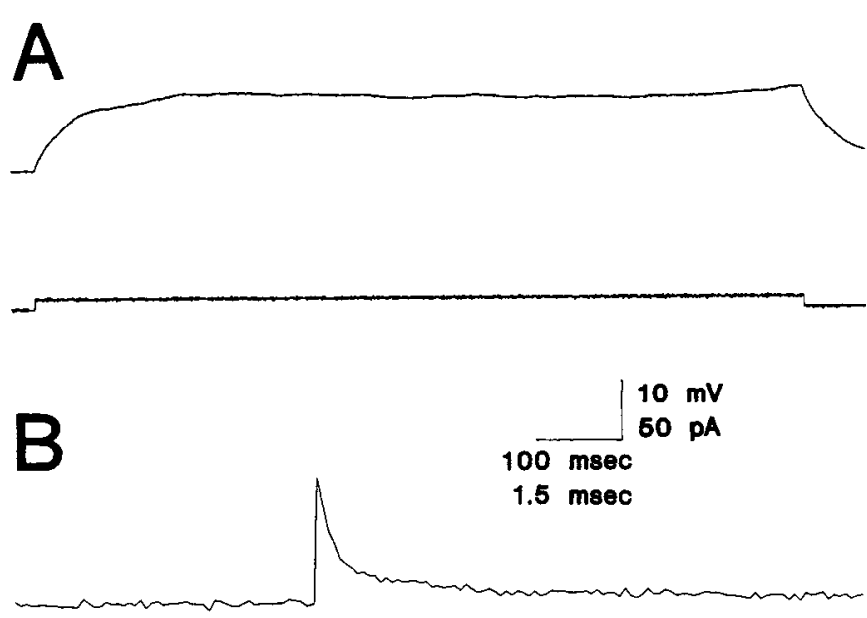

Figure 2. Measurements for electrical membrane constants and series resistance. $A$, Upper trace shows voltage response to a $10 \mathrm{pA}$ step of current shown in lower trace. The time constant, determined from the voltage response, is $20 \mathrm{msec}$. Plateau voltage was $13.4 \mathrm{mV}$, giving an input resistance of $1.34 \mathrm{G} \Omega$ and membrane capacitance of $15 \mathrm{pF} . B$, Determination of electrode series resistance. Capacitive transient recorded under voltage clamp (upper trace) in response to a $5 \mathrm{mV}$ step (lower trace). Time constant was $0.15 \mathrm{msec}$. With membrane capacitance of $15 \mathrm{pF}$, calculated series resistance was $10 \mathrm{M} \Omega$.

$-15 \mathrm{mV}$, similar to that of other membranes (Cole and Moore, 1960; Lasater, 1986; Lipton and Tauck, 1987). The reversal potential for this current was near $+45 \mathrm{mV}$. Table 4 summarizes the statistics for the whole-cell inward current data for all cells studied.

Inactivation of transient inward current. Inactivation of the transient inward current was measured in the conventional way by preceding a fixed magnitude depolarizing test pulse to -10 $\mathrm{mV}$ with a series of conditioning pulses to potentials ranging from -80 to $-15 \mathrm{mV}$ (Hodgkin and Huxley, 1952a, b). Figure $5 A$ shows the currents elicited following these conditioning steps, and Figure $5 B$ shows the inactivation curve derived from these measurements.

In 8 cells, inactivation began at potentials more positive than $-65 \mathrm{mV}$ and was nearly complete at $-25 \mathrm{mV}$. For potentials more positive than $-35 \mathrm{mV}$, the conditioning steps themselves entered the activation range, and inactivation was therefore overestimated. The inactivation range is very similar to that found in rat (Lipton and Tauck, 1987).

The transient inward current was eliminated by $0.33 \mu \mathrm{M}$ or more TTX (solution D) (Moore et al., 1967). These observations, along with the measured reversal potential of $+45 \mathrm{mV}$, are consistent with the notion that the transient inward current is carried by sodium.

Sustained inward currents. A sustained inward current, elicited by depolarizing voltage steps, could be measured by block-

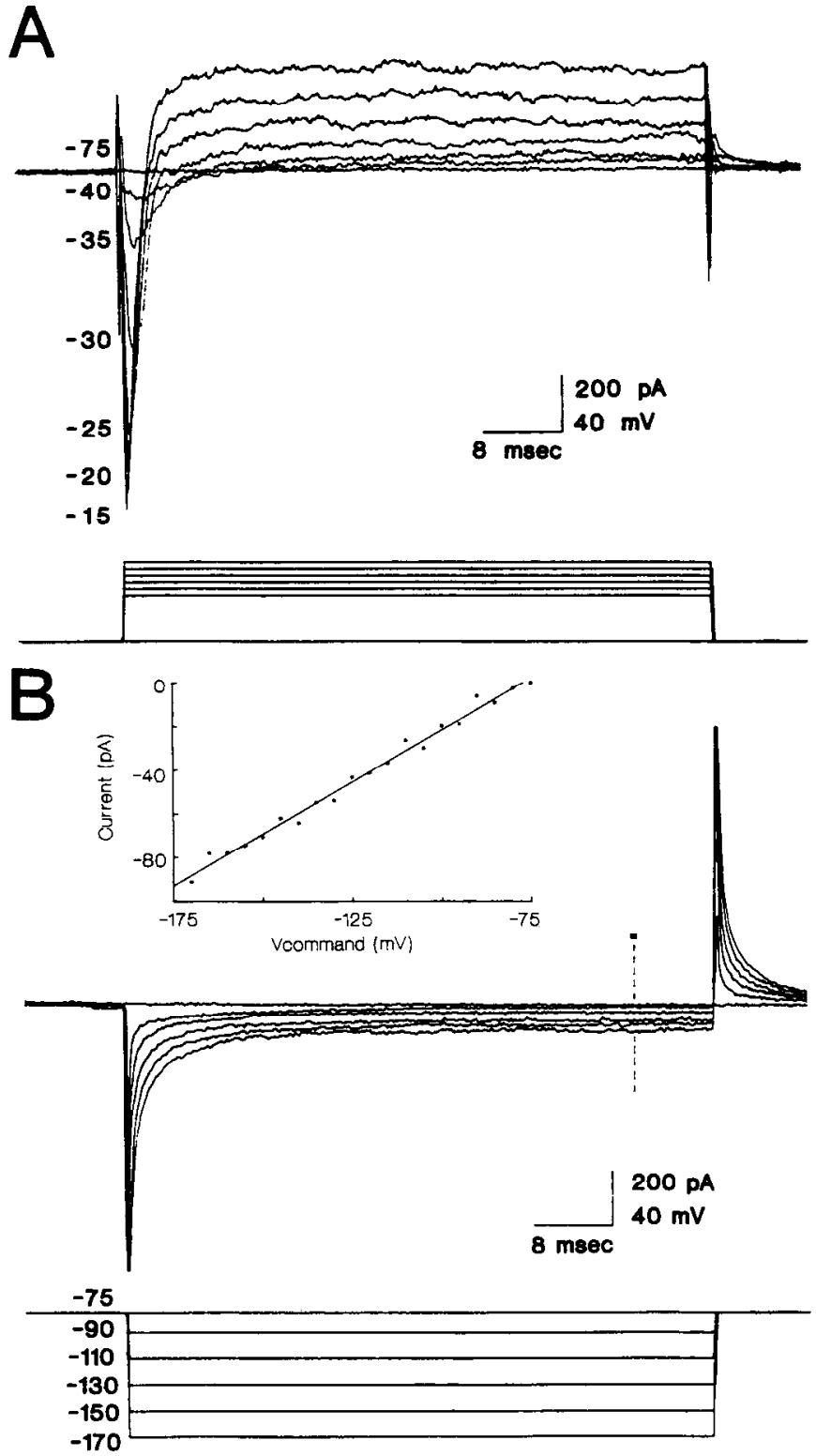

Figure 3. Whole-cell currents. $A$, Responses to depolarizing voltage steps. Holding potential was $-75 \mathrm{mV}$. Electrode solution $\mathrm{A}$; bathing solution $A$. In this and subsequent figures, the upper traces are current responses and lower traces show time course and magnitude of voltage steps. Numbers near traces indicate the voltage to which the membrane was stepped. The capacitive and leak currents were mostly eliminated by subtraction of control records, but transients at the onset and offset of the current traces are remnants of the capacitive currents. $B, \mathrm{Re}-$ sponses to hyperpolarizing voltage steps. Inset, $I-V$ relation for hyperpolarizing steps. Measurements taken at the time indicated by the solid square in upper trace. Straight line is a least-squares fit. The input resistance was $1.1 \mathrm{G} \Omega$. Same cell used in $A$ and $B$.

ing the outward currents with $96 \mathrm{~mm}$ cesium and $20 \mathrm{~mm}$ TEA in the recording electrode and by blocking the sodium current with TTX in the bathing solution. Of the 24 cells studied, activation began between -45 and $-30 \mathrm{mV}$. Selected currents

Figure 1. Photomicrograph of a retinal slice in which the axon was allowed to take up rhodamine before dissection (see Materials and Methods). In this and 12 other retinas examined, almost all ganglion cells were stained, and very few cells in the inner nuclear layer were ever stained. This suggests that most cells at the inner margin of the retina are ganglion cells (have axons) and that virtually no cells in the inner nuclear layer are ganglion cells. The observation verifies our assertion that the measurements both in slices and isolated cells were taken from ganglion cells. The slice was transilluminated with green light and epiilluminated and viewed through a $580 \mathrm{~nm}$ barrier filter, giving the rhodamine cells an orange appearance. 

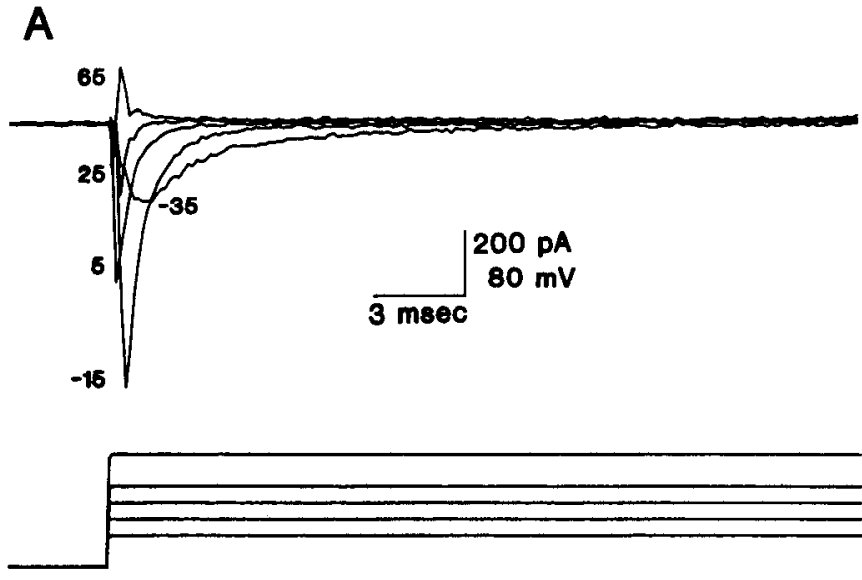

B

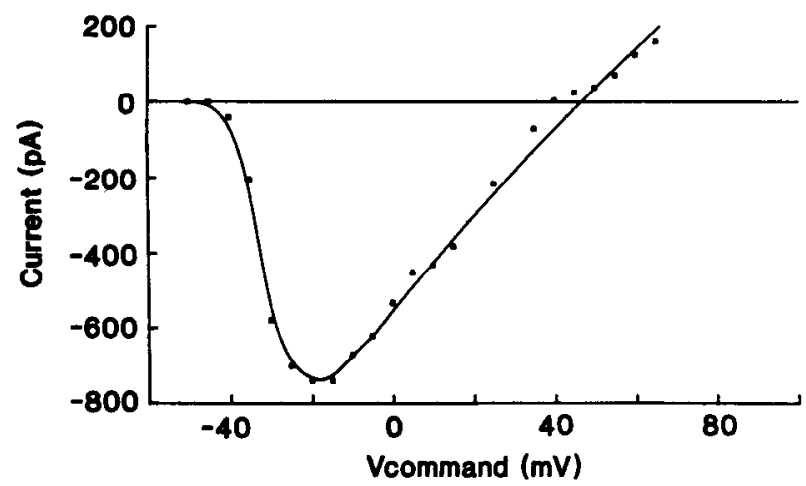

Figure 4. A, Isolation of the inactivating inward current. Holding potential was $-75 \mathrm{mV}$. Cs/TEA (solution D) was used in electrodes and bathing solution contained $2 \mathrm{mM}$ Co (solution B). Capacitive and lcak currents were subtracted. $B$, Current-voltage relation for inactivating inward current. Points measured at response peak for every 5 $\mathrm{mV}$ voltage increment.

from a typical cell are shown in Figure $6 A$ for a cell held at -75 $\mathrm{mV}$ and stepped to the indicated potentials.

The current-voltage relationship, measured at the peak response, for the complete set of voltage steps is shown in Figure $6 B$. The current began to activate at $-35 \mathrm{mV}$ and reached a maximum of $280 \mathrm{pA}$ near $-5 \mathrm{mV}$, similar to that described for
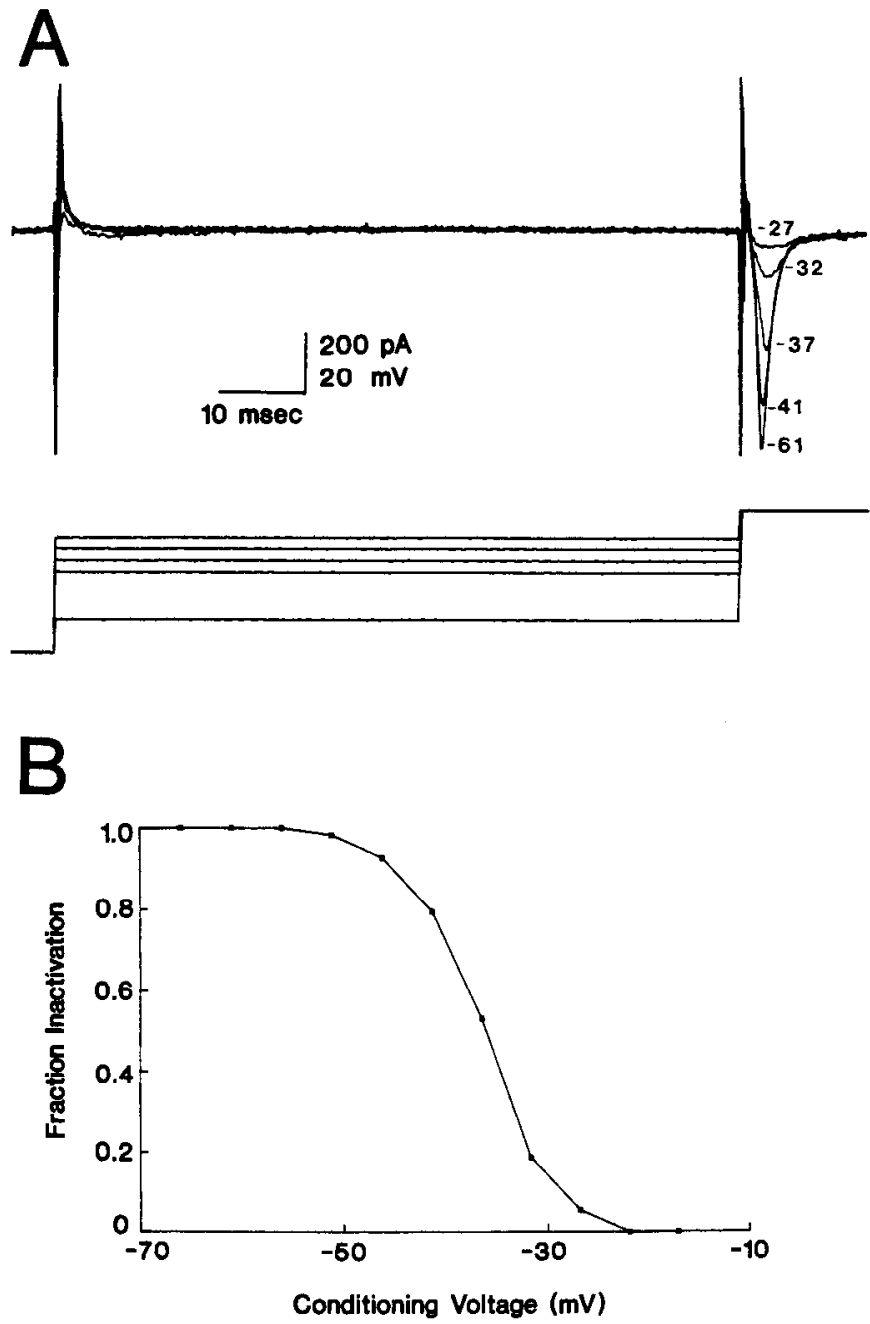

Figure 5. Inactivation of inward current. $A$, Response currents. Holding potential was -75 . Cs/TEA electrode solution D was used and Ringer contained $2 \mathrm{~mm}$ Co and no added $\mathrm{Ca}$ (solution B). Capacitive artifacts and leak currents were not subtracted. $B$, Inactivation curve for cell in $A$ given as the fraction of maximal current (measured at peak) versus the magnitude of the conditioning voltage.

other retinal cells (Kaneko and Tachibana, 1985; Lasater, 1986; Lipton and Tauck, 1987). For potentials more positive than -5 $\mathrm{mV}$, the current decreased. Statistics for other cells are compiled in Table 4.

\begin{tabular}{|c|c|c|c|c|}
\hline Parameter & Range & $n$ & Mean & SEM \\
\hline \multicolumn{5}{|l|}{ Sodium activation } \\
\hline Beginning of activation (mV) & -40 to -29 & 16 & -37.6 & 0.45 \\
\hline Peak current voltage $(\mathrm{mV})$ & -20 to -5 & 15 & -12.8 & 1.26 \\
\hline Peak current amplitude (nA) & -0.84 to -2.2 & 14 & -1.32 & 0.13 \\
\hline \multicolumn{5}{|l|}{ Potassium activation } \\
\hline Beginning of activation (mV) & -39 to -28 & 15 & -33.1 & 1.05 \\
\hline Amplitude at $-15 \mathrm{mV}(\mathrm{nA})$ & $0.111-0.966$ & 15 & 332.7 & 53.1 \\
\hline \multicolumn{5}{|l|}{ Passive membrane properties } \\
\hline Input resistances $(\mathrm{G} \Omega)$ & $0.878-10$ & 33 & 2.9 & 0.39 \\
\hline Membrane capacitance (pF) & $9-40$ & 15 & 21.25 & 2.26 \\
\hline Membrane time constants (msec) & $18-52$ & 15 & 41.3 & 3.04 \\
\hline Resting levels (mV) & -52 to -91 & 41 & -67.5 & 1.5 \\
\hline
\end{tabular}



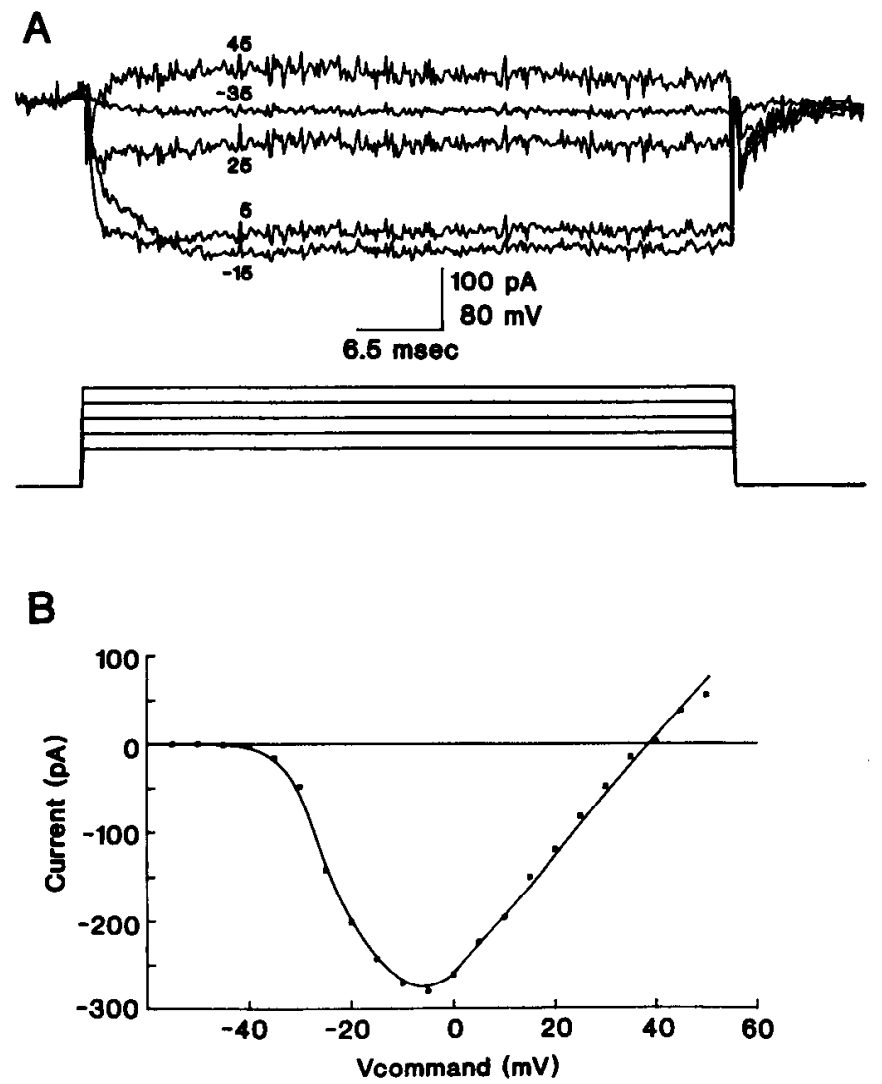

Figure 6. Isolation of the calcium current. $A$, Sustained inward currents. Cs/TEA electrode solution D was uscd and Ringer contained 1 $\mu \mathrm{M}$ TTX (solution C). Capacitive and leak currents were subtracted. Noise at more positive potentials was due to scaling and subtracting small responses in control steps. $B$, Current-voltage relation for the sustained inward current for cell in $A$. Current was maximal at $-5 \mathrm{mV}$ and reversed near $+40 \mathrm{mV}$.

The reversal potential for this current was near $40 \mathrm{mV}$ and is similar to that reported by others (Fenwick et al., 1982; Lee and Tsien, 1982; Lipton and Tauck, 1987). The reversal potential is more negative than the calculated reversal potential for the calcium current, possibly because of an outward current carried by cesium or other ions through the calcium channels.

The sustained inward current inactivated very slowly, with time constants between $3.3-1.3 \mathrm{sec}$ for voltage steps ranging from -30 to $-5 \mathrm{mV}$, respectively. This current decreased in magnitude or "ran down" over a period of 5-10 min during a sequence of measurements.
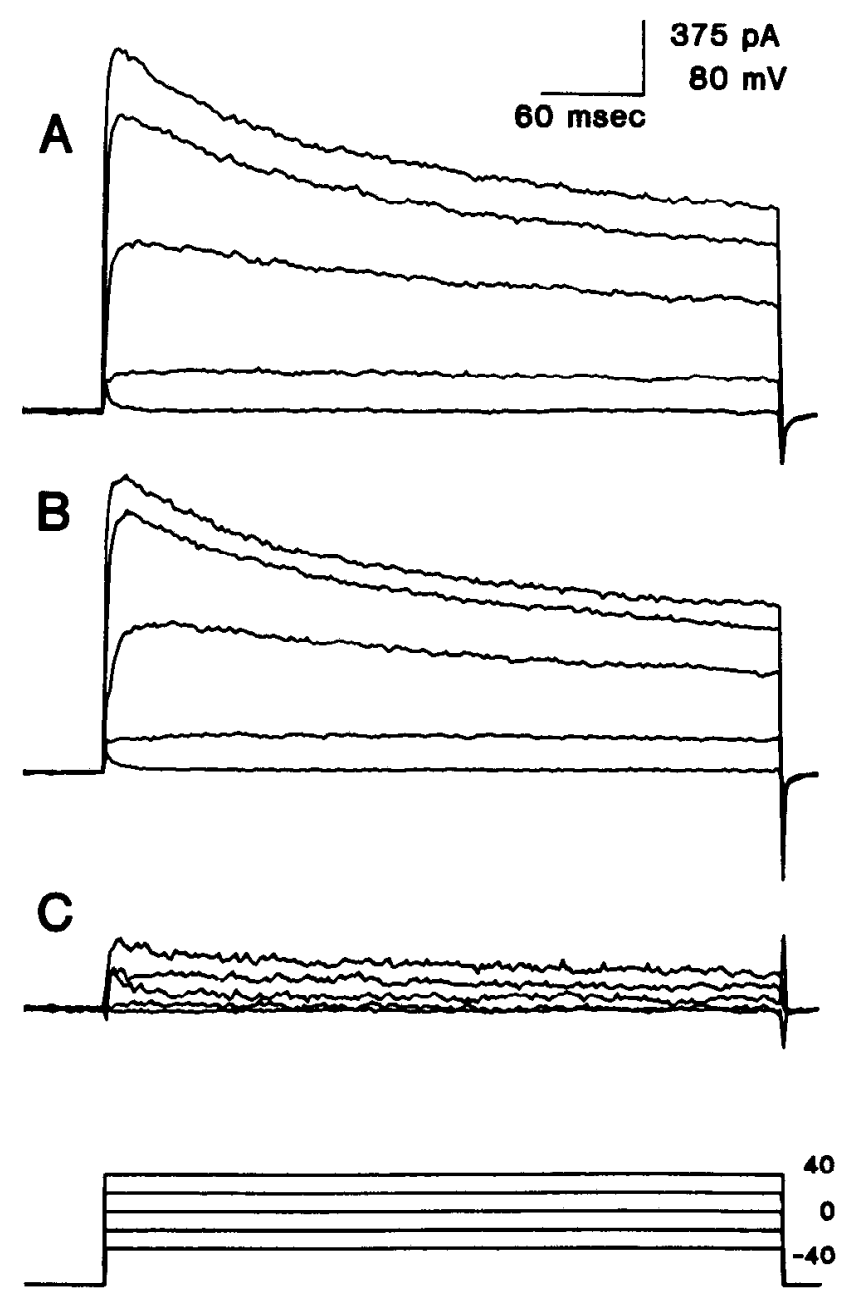

Figure 7. Cobalt-blocked components of outward currents. $A$, Total outward currents. Responses to potentials indicated by the stimulus traces. Holding potential was $-80 \mathrm{mV}$. $\mathrm{KCl}$ electrode solution $\mathrm{B}$ was used and Ringer contained $1 \mu \mathrm{M}$ TTX (solution C). $B$, Outward current responses in the presence of $2 \mathrm{mM}$ Co and no added $\mathrm{Ca}$ (solution $\mathrm{D}$ ). Same potentials as in $A$. $C$, Measured calcium-dependent outward currents determined by subtracting the currents in $B$ from the total outward currents in $A$. This record is an underestimate of the full potassium current because a component of calcium current (Fig. 6) also exists. The calcium-activated potassium currents are sustained, and the calcium currents are relatively sustained, inactivating very slowly (see text).

This current was blocked by $\mathrm{Co}^{2+}$ (1-4 mM; see Fig. 4A) (Weakly, 1973) but was unaffected by TTX or choline substitution. These observations and the reversal potential near +40 $\mathrm{mV}$ suggest that it is carried primarily by calcium.

\begin{tabular}{lllll}
\hline Table 4. Inward currents & & & & \\
Parameter & Range & & Mean & SEM \\
\hline Transient inward currents & & & & \\
$\quad$ Beginning of activation $(\mathrm{mV})$ & -45 to -30 & 21 & -37.9 & 0.79 \\
Peak current voltage $(\mathrm{mV})$ & -20 to -3 & 21 & -12.4 & 1.34 \\
Maximum current (nA) & -0.329 to -2.2 & 19 & -0.968 & 0.123 \\
Half inactivation voltage $(\mathrm{mV})$ & -38.3 to -44 & 8 & -41.5 & 0.63 \\
Sustained inward currents & & & & \\
$\quad$ Beginning of activation (mV) & -45 to -23 & 24 & -34.7 & 0.79 \\
Peak current voltage (mV) & -5 to 17 & 23 & 4.4 & 1.56 \\
Maximum current (nA) & -0.17 to -0.5 & 23 & -0.326 & 22.7 \\
\hline
\end{tabular}




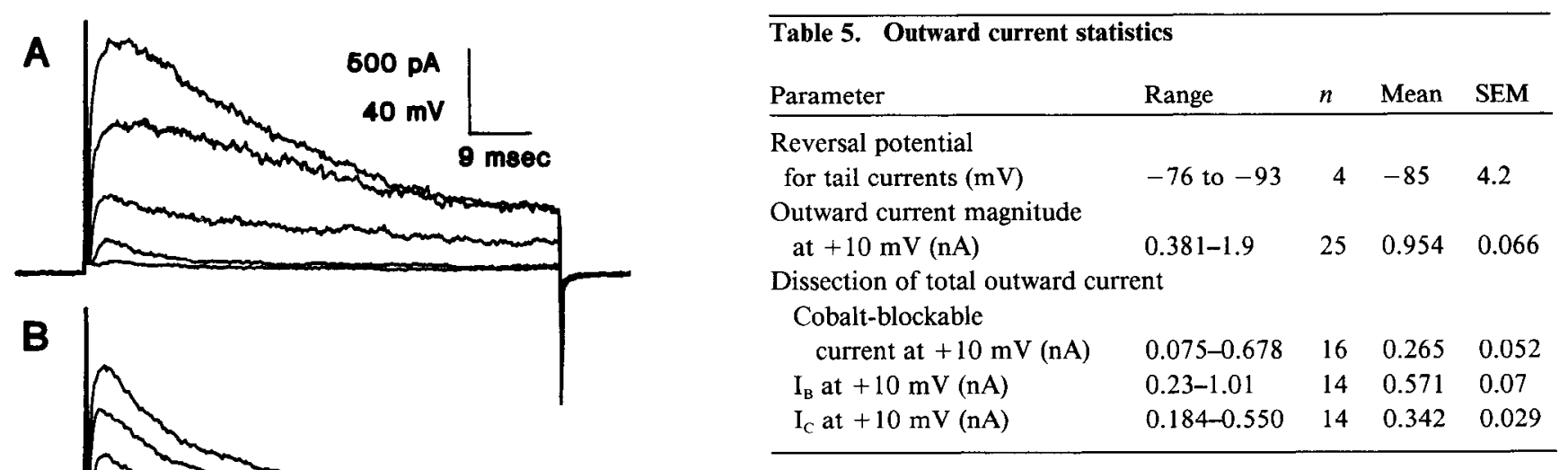

component of the outward current (Meech and Standen, 1975) was determined by subtracting the currents measured in the presence of $2 \mathrm{mM} \mathrm{Co}^{2+}$ and $0 \mathrm{mM} \mathrm{Ca}^{2+}$ (as shown in Fig. $7 B$ ) from the complete currents (shown in Fig. 7A). The difference is shown in Figure $7 C$. This current appears to be sustained at all potential levels. Because the calcium-activated potassium current is offset by a steady calcium current, the magnitude of the outward component shown here is an underestimate of the true value.

Fast inactivating current: $I_{A}$. The fastest transient component of the outward current was blocked by 1-2 mM 4-AP (Thompson, 1977; Lipton and Tauck, 1987). This current was revealed by subtracting records taken in the presence of 4-AP from those in its absence. Figure $8 A$ shows the total outward current in the presence of $2 \mathrm{mM} \mathrm{Co}^{2+}$ and TTX (solution D). Figure $8 B$ shows currents measured in the presence of $\mathrm{Co}^{2+}$, TTX, and $20 \mathrm{mM}$ TEA (solution E). Figure $8 C$ shows currents measured in the presence of $\mathrm{Co}^{2+}$, TTX, TEA, and $2 \mathrm{~mm}$ 4-AP. Figure $8 D$, the difference between the outward currents measured in the presence of 4-AP (Fig. 8C) and its absence (Fig. $8 B$ ), reveals a current with very short time course, less than $15 \mathrm{msec}$.

This rapidly inactivating current was not present in all cells, and in some cells a slower current was also blocked by 4-AP (Hermann and Gorman, 1981).

The TEA-sensitive component of the outward current is shown in Figure $8 E$, derived by subtracting the currents measured in the presence of TEA (Fig. $8 B$ ) from those in its absence (Fig. $8 A$ ). The more slowly inactivating outward currents described below were TEA sensitive.

\section{More slowly inactivating outward currents: $I_{B}$ and $I_{C}$}

In the presence of cobalt and ITX, 2 additional, more slowly inactivating outward currents remained. They are shown, on a slower time scale, by the dotted trace in Figurc $9 A$. Their decay could be approximated by a pair of exponentials. The time constants for the exponentials were determined by first fitting the slow component of the decay using the last $1000 \mathrm{msec}$ of the trace. This slow exponential $(\tau=4.03 \mathrm{sec})$ was then peeled away from the original trace, leaving another exponential that could be fitted with a faster time constant $(\tau=339 \mathrm{msec})$.

The solid line in Figure $9 A$, composed of these 2 exponentials, provides an excellent fit to the original trace. The time courses for the decay of the 2 exponential current components, the slow component (dots) and faster component (crosses), are shown separately in Figure $9 B$.

The total outward currents recorded in the presence of TTX and $\mathrm{Co}$ are shown in Figure 10A. 4AP reduced the time to peak

The calcium-activated current: $I_{K(C a)}$. The calcium-activated 

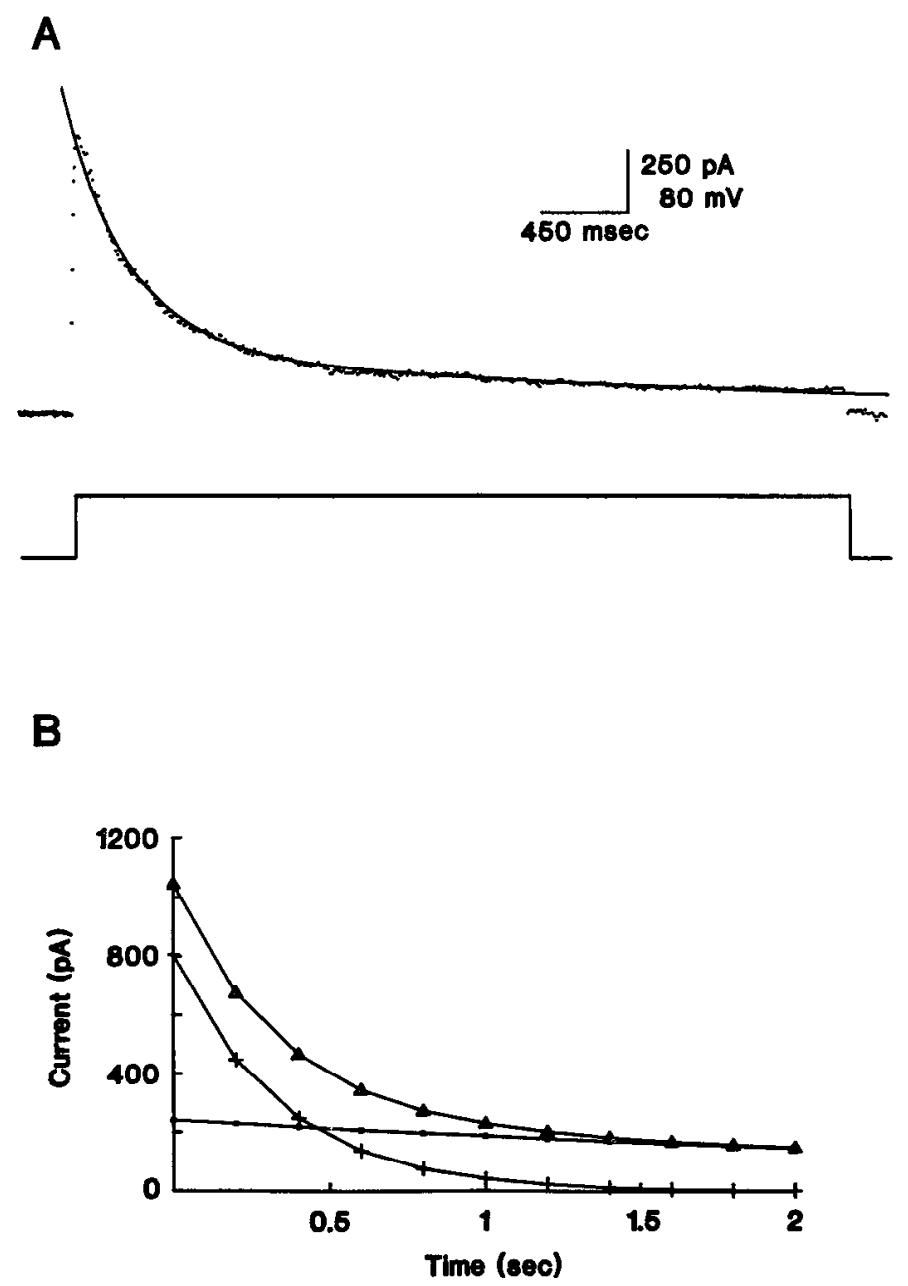

Figure 9. Double-exponential fit of slowly inactivating outward currents $\mathrm{I}_{\mathrm{B}}$ and $\mathrm{I}_{\mathrm{C}}$. A, Dotted trace is the outward current in response to a step to $0 \mathrm{mV}$ in the presence of TTX and $\mathrm{Co}^{2+}$. Holding potential was $-80 \mathrm{mV}$. Solid line is the best double-exponential fit. $\tau_{\mathrm{B}}$ was $339 \mathrm{msec}$ and $\tau_{C}$ was $4.03 \mathrm{sec} . B$, The time course of decay for the total (open triangles), $\mathbf{I}_{\mathrm{B}}$ (crosses), and $\mathrm{I}_{\mathrm{C}}$ (dots) outward current components.

for these currents, so the rise time in Figure $10 B$ is slower than in Figure $10 \mathrm{~A}$, due to the blockade of $\mathrm{I}_{\mathrm{A}}$. $4 \mathrm{AP}$ did not affect the more slowly decaying currents (Fig. 10B) and the remaining current in $10 B$ resembles that of Figure $10 A$. $\mathrm{I}_{\mathrm{C}}$, the most slowly inactivating current, was isolated by inactivating $I_{B}$ with a 1.2 sec conditioning pulse to $0 \mathrm{mV}$ (Fig. $10 \mathrm{C}$ ).

The slowly inactivating outward currents, $I_{B}$ and $I_{C}$, were isolated by taking advantage of the large disparity in their time constants of inactivation. We showed in Figure 9 that at $1.2 \mathrm{sec}$ $I_{B}$ is almost completely inactivated. The magnitude $I_{C}$ is, however, underestimated since it is slightly inactivated at $1.2 \mathrm{sec}$ (see below). $\mathrm{I}_{B}$ was obtained by subtracting $\mathrm{I}_{C}$ (Fig. 10C) from the currents that remained in the presence of $\mathrm{Co}$ and $4 \mathrm{AP}$ (Fig. $10 D)$.

\section{Voltage-dependent inactivation of $I_{B}$}

The voltage-dependence of inactivation of $\mathrm{I}_{\mathrm{B}}$ was measured in the conventional way by preceding a depolarizing test pulse from $-80 \mathrm{mV}$ to $+10 \mathrm{mV}$ with conditioning pulses to different potential levels as shown in Figure 11 A. It was important to determine the optimum duration for the conditioning pulse used to inactivate $I_{B}$ since the measurement could be contaminated

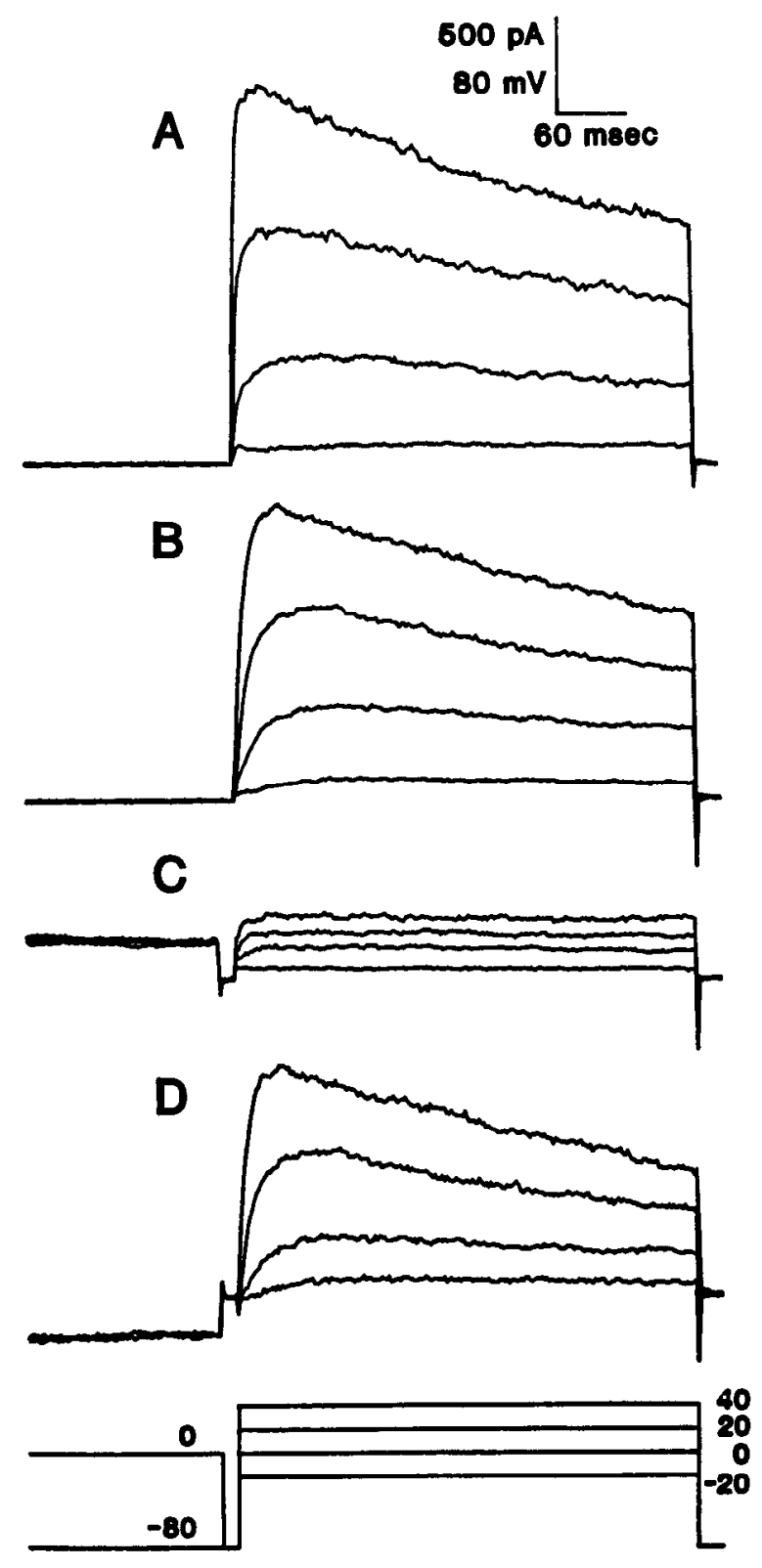

Figure 10. Separation of slowly inactivating currents, $\mathrm{I}_{\mathrm{B}}$ and $\mathrm{I}_{\mathrm{C}} . A$, Outward current responses to the potentials indicated by the stimulus traces. The membrane was held at $-80 \mathrm{mV}$. KCl electrode solution B was used, and the Ringer contained $1 \mu \mathrm{M}$ TTX, $2 \mathrm{mM} \mathrm{Co}$, and no added $\mathrm{Ca}$ (solution D). All outward currents except $\mathrm{I}_{\mathrm{K}(\mathrm{Ca})}$ are present. $B, \mathrm{Re}-$ sponses after $1 \mathrm{~mm} 4 \mathrm{AP}$ was added to the bath. 4AP blocked a sustained component of the outward current in addition to $I_{A}$. $C$, Responses after $0 \mathrm{mV}$ conditioning level for $1.2 \mathrm{sec}$ prior to the voltage steps. These conditions eliminate $I_{B}$. $D$, Transient outward current $I_{B}$ alone, determined by subtracting the sustained outward currents $\mathrm{I}_{C}$ in $C$ from the composite outward currents in the presence of $4 \mathrm{AP}(B)$.

by $I_{C}$, which also inactivates, albeit much more slowly. The optimal duration for the conditioning pulse used to inactivate $I_{B}$ should inactivate as much of $I_{B}$, but as little of $I_{C}$, as possible. This duration can be found from the solution of the equation:

$$
\frac{d}{\mathrm{dt}}\left[\left(e^{-t / \tau B}\right)-\left(e^{-t / \tau \mathrm{C}}\right)\right]=0,
$$

where $\tau_{\mathrm{B}}$ and $\tau_{\mathrm{C}}$ are the inactivation time constants for the fast and slow components, respectively. The quantity in brackets is 

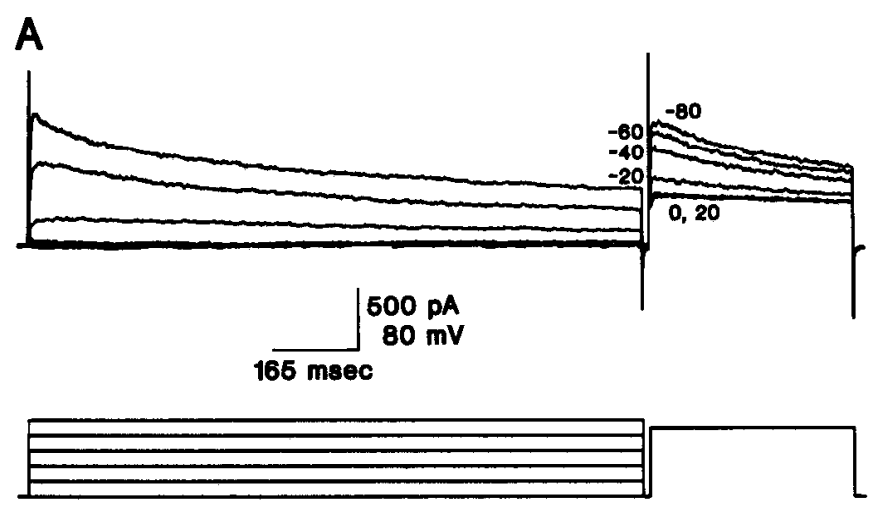

$\mathbf{B}$

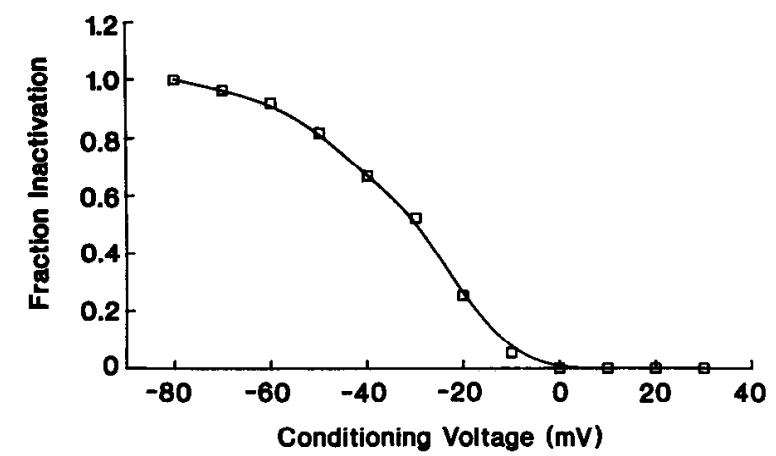

Figure 11. Inactivation of $\mathrm{I}_{\mathrm{B}} . A$, Current responses to a test pulse to $110 \mathrm{mV}$ preceded by conditioning pulses to different potentials as indicated near the responses. $\mathrm{KCl}$ solution $\mathrm{B}$ was used and the Ringer contained $1 \mu \mathrm{M}$ TTX and $2 \mathrm{~mm}$ Co but no added Ca (solution D). $B$, Inactivation curve for $I_{B}$. The percentage of the peak maximum outward current was plotted as a function of the magnitude of the conditioning pulse at $30 \mathrm{msec}$, a time at which $\mathbf{I}_{\mathrm{A}}$ was fully decayed (see Fig. 9). the difference in the fraction of the 2 remaining components as a function of time. When its derivative (in time) is zero, that difference is greatest. The solution to equation (1) is

$$
t=\tau_{\mathrm{C}} \tau_{\mathrm{B}} /\left(\tau_{\mathrm{C}}-\tau_{\mathrm{B}}\right)\left[\ln \tau_{\mathrm{C}}-\ln \tau_{\mathrm{B}}\right] .
$$

Equation 2 predicts that, for a step to $0 \mathrm{mV}$, the difference between the remaining magnitudes of $I_{B}$ and $I_{C}$ will be greater than $71 \%$ between 0.7 and 1.2 sec.

We measured the inactivation range of $I_{B}$ with a conditioning pulse of $1.2 \mathrm{sec}$ duration, when $3 \%$ of $\mathrm{I}_{\mathrm{B}}$ and $74 \%$ of $\mathrm{I}_{\mathrm{C}}$ remained for a fully inactivating conditioning pulse, as shown in Figure $9 B$. We were able to measure the changes in magnitude of $I_{B}$ after conditioning pulses to different potential levels by stepping to $+10 \mathrm{mV}$ but measuring the current $30 \mathrm{msec}$ later to allow $\mathrm{I}_{\mathrm{A}}(\tau \leq 20 \mathrm{msec})$ to decay. Inactivation of $\mathrm{I}_{\mathrm{B}}$ was very broad, spanning the potential range from -80 to $0 \mathrm{mV}$ (Fig. 11B).

Reversal potential for outward currents. We determined the reversal potential for the outward current from the sign and magnitude of the decay of the fully activated currents measured at different potential levels as shown in Figure 12. Calcium currents, which could offset the outward current reversal potential, were eliminated with $2 \mathrm{mM} \mathrm{Co}{ }^{2+}$ replacing calcium in the bathing medium. This also eliminated one component of the outward current, $I_{\mathrm{K}(\mathrm{Ca})}$.

The membrane was held at $-80 \mathrm{mV}$ and first stepped to 0 $\mathrm{mV}$, where a significant fraction of the current was activated; then it was stepped to potentials between -55 and $-110 \mathrm{mV}$. Figure $12 A$ shows some selected currents, and Figure $12 B$ shows the current-voltage curve using currents measured at all steps. The reversal potential derived from the least-squares fit is -77 $\mathrm{mV}$. Similar results were found in 3 additional cells $(-85 \mathrm{mV}$ mean; see Table 5).

These currents were blocked by internal cesium and TEA, which suggests that they were potassium currents. The measured reversal potential at $-77 \mathrm{mV}$ is more positive than the calculated Nernst potential for potassium of $-100 \mathrm{mV}$, possibly because the potassium channels are relatively nonselective.

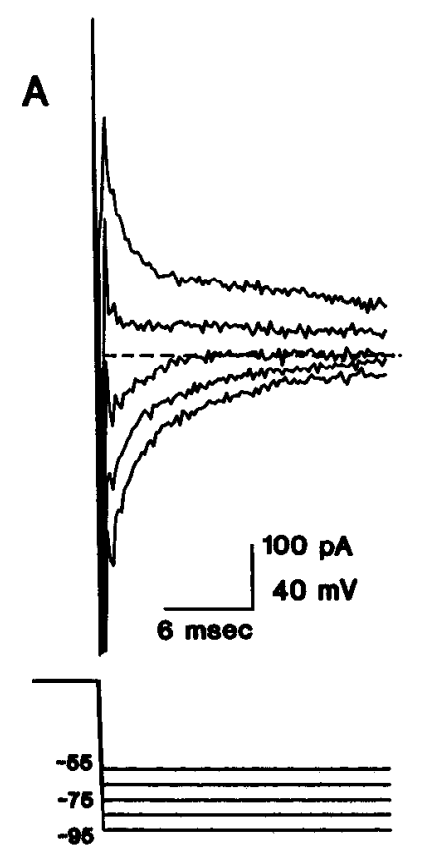

B

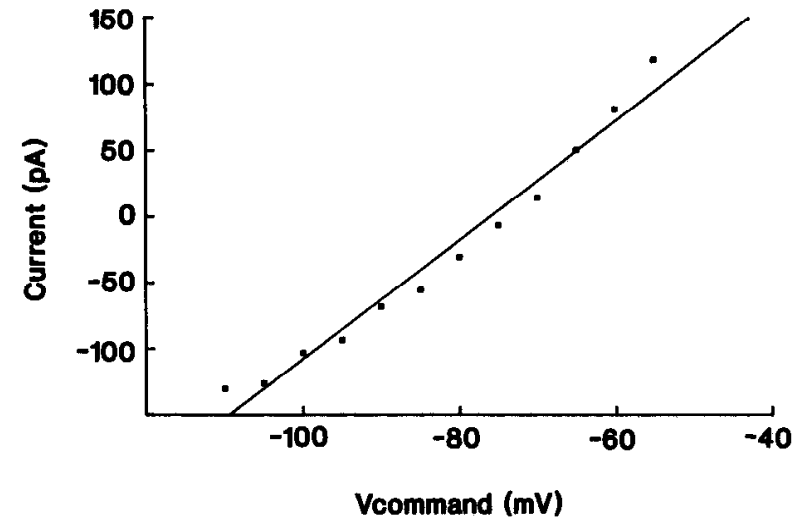

Vcommand (mV)
Figure 12. Reversal of the potassium tails. $A$, The membrane was held at -80 $\mathrm{mV}$, then stepped from $0 \mathrm{mV}$ in successive records to -110 to -55 in 5 $\mathrm{mV}$ increments. $\mathrm{KCl}$ electrode solution $B$ was used and Ringer contained $1 \mu \mathrm{M}$ TTX and 2 mM Co (solution D). Measurements were made $5.4 \mathrm{msec}$ after the end of the step to avoid the capacitive transient. $B$, Current-voltage relation for currents for all steps over the full range of potentials. Tails reversed at $-77 \mathrm{mV}$. 


\section{Spike activity in response to current steps}

The presence of the inactivating current, $I_{B}$, suggests that its role in modulating the spike output of ganglion cells might be manifest in a membrane potential change with similar time constant. We looked under current clamp at the spike activity, and identified a slow depolarization of the membrane with time course similar to that of $I_{B}$. Then we eliminated other currents to confirm that these slow changes in spiking were mediated by $I_{B}$.

For relatively large input currents the spike train was terminated before the end of the current step. Figure 13 shows the normal spike train elicited at a series of current steps of increasing magnitude. With $10 \mathrm{pA}$ of current the membrane was steadily depolarized and a series of spikes of relatively constant interspike interval was generated for the duration of the current step. With a $20 \mathrm{pA}$ step, the spike frequency increased, and the membrane potential and spike rate were relatively sustained for the duration of the step. However, at $30 \mathrm{pA}$ the spike train was truncated after about $500 \mathrm{msec}$ and the membrane potential became gradually more positive during the step. For a $40 \mathrm{pA}$ step the spike train was truncated even earlier.

\section{The $I_{B}$ current underlies slow membrane potential changes}

The membranc currents for steps to $-30,20$, and $-10 \mathrm{mV}$ were fit over the first $300 \mathrm{msec}$ with exponentials. These cur-

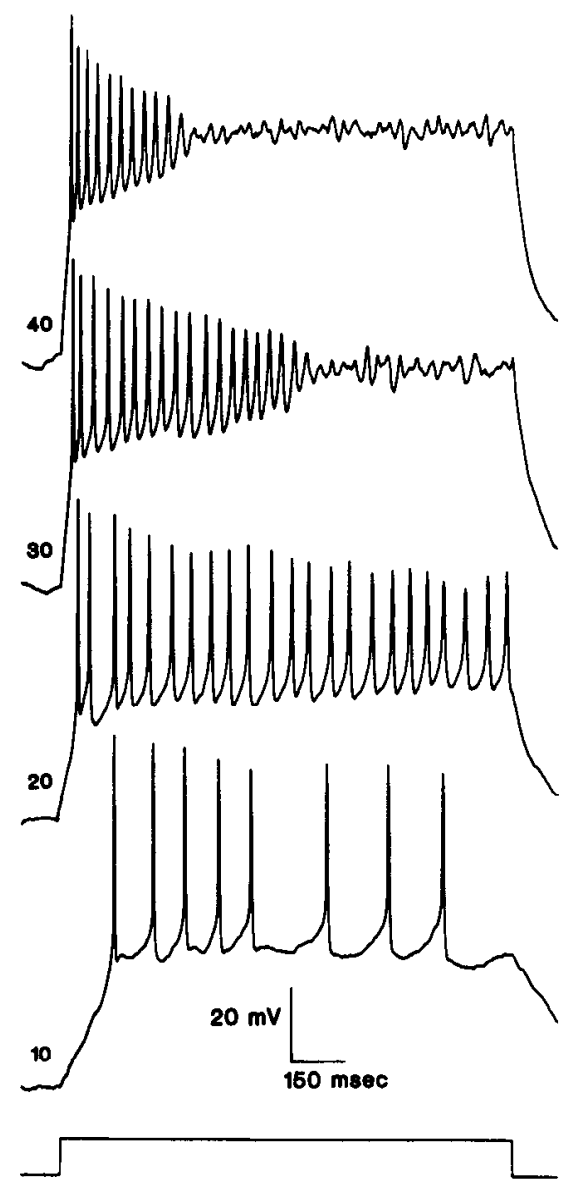

Figure 13. Spike activity at different input current magnitudes. Current step magnitudes in $\mathrm{pA}$ are shown to the left of each trace. $\mathrm{KCl}$ solution $\mathrm{B}$ was in the electrode and control Ringer (solution A) was in the bath. Spike rates are constant for 10 and $20 \mathrm{pA}$ steps, but spikes are truncated as the membrane potential rises to more positive levels for 30 and 40 pA steps. rents, taken from the same cell as in Figure 13, had time constants of 240,270 , and $350 \mathrm{msec}$, respectively, as shown in Figure 14. These are consistent with the $339 \mathrm{msec}$ time constant taken from the step to $0 \mathrm{mV}$ shown in Figure 9.

We show that $I_{B}$ underlies these currents by eliminating each of the other voltage-gated current components as shown in Figure 15 . Figure $15 A$ shows the normal spike activity elicited by a $30 \mathrm{pA}$ current step. Figure $15 B$ shows the behavior of the spike train in the presence of $4 \mathrm{AP}\left(\mathrm{I}_{\mathrm{A}}\right.$ blocked). 4AP decreased spike frequency, an effect different from that predicted by Conner and Stevens $(1971 \mathrm{a}, \mathrm{b})$. In many cases, $\mathrm{I}_{\mathrm{A}}$ does not play a significant role in truncating spike activity. When the spiking was blocked with TTX, as in Figure $15 C$, the gradual membrane depolarization during the course of the current step became more apparent. Blocking the calcium current with $\mathrm{Co}^{2+}$ did not affect this gradual depolarization during the step as shown in Figure 15D. A relationship between the exponential change in $I_{B}$ shown in Figure 14, and the exponentiallike change in potential in Figure 15 is derived in the Discussion.

\section{Discussion}

Roles of inactivating outward currents. A variety of inactivating outward currents with different inactivation time constants, potential ranges, and pharmacological sensitivities have been described earlier. The fastest of these, $I_{A}$, has been implicated as a factor modulating spike frequency by Conner and Stevens (1971a) and Adams et al. (1982). This current, with time constant between 5 and $100 \mathrm{msec}$, depending upon preparation, has been identified by its sensitivity to 4AP and has been found
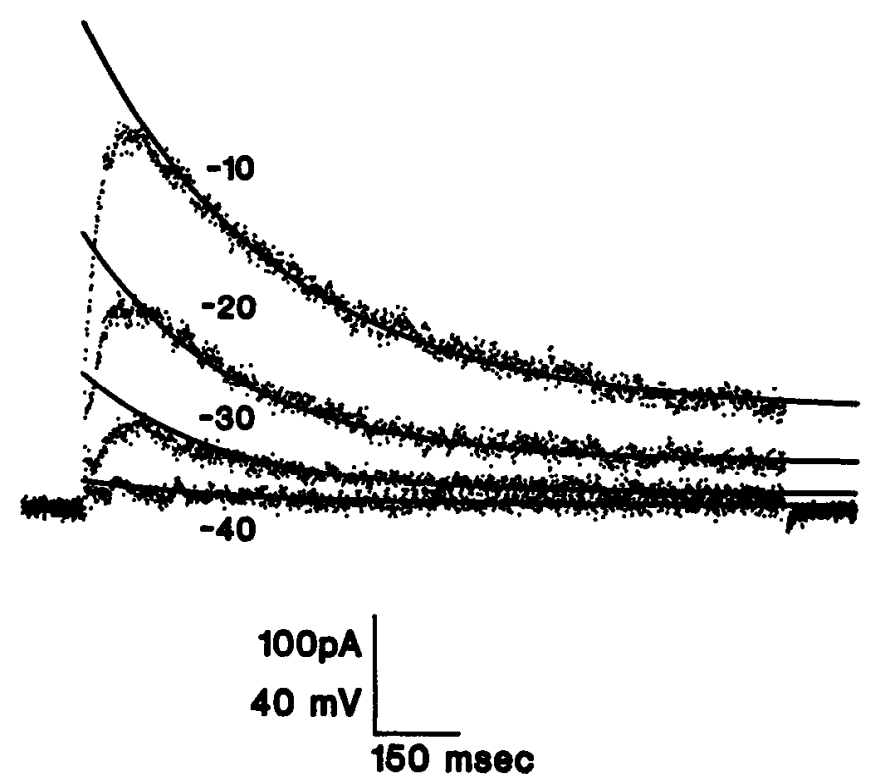

Figure 14. Fitting $I_{B}$ currents with exponentials. Records taken in the same cell as in Figures 13 and 15. Measurement made in the presence of $2 \mathrm{mM} \mathrm{Co}^{2+}, 1 \mu \mathrm{M}$ TTX, and $2 \mathrm{~mm} 4 \mathrm{AP}$. Fits were made over the first $300 \mathrm{msec}$ after the peak. The time constants for these curves were 240 $\mathrm{msec}$ at $-40 \mathrm{mV}, 250 \mathrm{msec}$ at $-30 \mathrm{mV}, 270 \mathrm{msec}$ at $-20 \mathrm{mV}$, and $330 \mathrm{msec}$ at $-10 \mathrm{mV}$. These fits suggest that $I_{B}$ is a single-exponential current with a distinct time course at each potential. 
by us in tiger salamander and by Lipton and Tauck (1987) in rat ganglion cells.

A second class of inactivating outward current, lacking 4AP sensitivity and having slower kinetics and activation ranges, has been described by Aldrich et al. (1979) (also see Adrian et al., 1970). This corresponds more closely to the current $I_{B}$ described here. Finally, a much more slowly inactivating outward current was described by Schwartz and Vogel (1971) with time constant between $600 \mathrm{msec}$ and $3.5 \mathrm{sec}$. This may be similar to the very slowly inactivating outward current, $\mathrm{I}_{\mathrm{C}}$, described here.

\section{$I_{B}$ is responsible for the depolarizing shift in membrane potential}

$I_{B}$ appears to be responsible for the slow rise in potential following a steady input current as shown in Figure $15 \mathrm{D}$. The

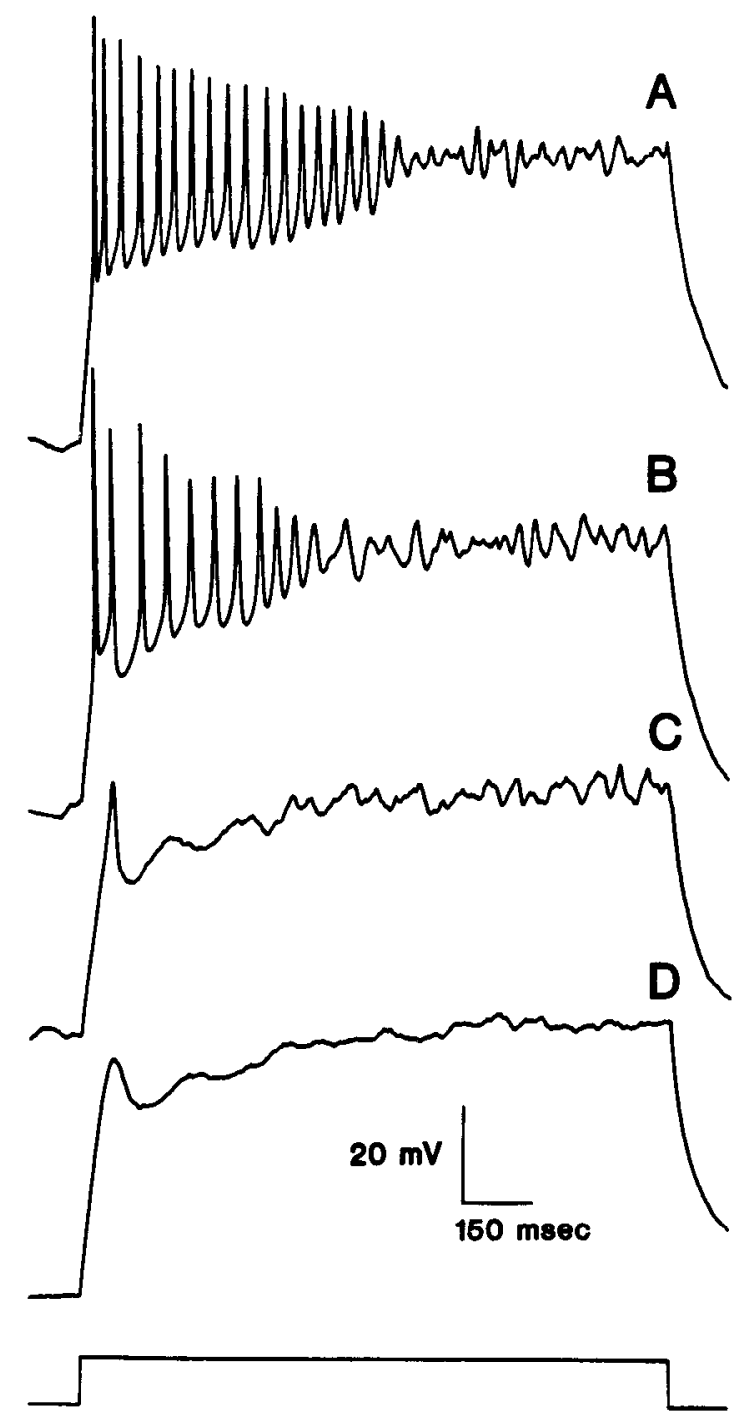

Figure 15. Membrane potential in absence of voltage-gated currents. $\mathrm{KCl}$ solution $\mathrm{B}$ was used in the electrode. $A$, Normal spike response to a $30 \mathrm{pA}$ step. $B, \mathrm{I}_{\mathrm{A}}$ is eliminated in the presence of $2 \mathrm{~mm} 4 \mathrm{AP}$. Spike activity decreases and membrane potential becomes more positive. $C$, Spiking is blocked in TTX, but membrane potential continues to increase during the step. $D$, In $\mathrm{Co}^{2+}$ calcium, current is blocked, but the membrane potential rise is unaffected. $I_{B}$ and upward change in potential remain intact in all records, suggesting a correlation. Same cell as Figure 13. association between $I_{B}$ and the rise is supported by the finding that the time constant for the underlying currents shown in Figure 14 and that of the potential rise are quite similar (Fig. $15 D)$.

Although the actual rise in potential in Figure $15 \mathrm{D}$ cannot be fit by an exponential, when the change in membrane slope conductance underlying the inactivation of $I_{B}$ itself is taken into account, the role of $I_{B}$ in mediating the potential change is strongly supported.

The rise in potential could not be fit with an exponential because the input slope resistance of the cell increases from 0.25 to $0.52 \mathrm{G} \Omega$ during the change in potential. This conductance decrease of $2.08 \mathrm{nS}$ is due almost entirely to the inactivation of $I_{B}$ since most other voltage-dependent potassium conductances have been blocked and $\mathrm{I}_{\mathrm{C}}$, being much slower, has not changed sufficiently during this interval. In fact, the conductance change calculated from the transient current $I_{B}$ between -40 and -20 $\mathrm{mV}$, assuming a reversal potential for potassium near $-80 \mathrm{mV}$, is also about $2 \mathrm{nS}$. In Figure 16 we were able to straddle the potential rise during the step by using $2 \mathrm{I}_{\mathrm{B}}$ exponentials, with $240 \mathrm{msec}$ time constant but differing in magnitude to take into account the change in chord conductance: The lower exponential is the voltage using the initial input resistance of $0.25 \mathrm{G} \Omega$, and the upper exponential is that using the final input resistance of $0.52 \mathrm{G} \Omega$. The time constant changes only from 240 to $270 \mathrm{msec}$ over this potential range, so the fit using a time constant of 240 msec is a reasonable approximation. These curves show that

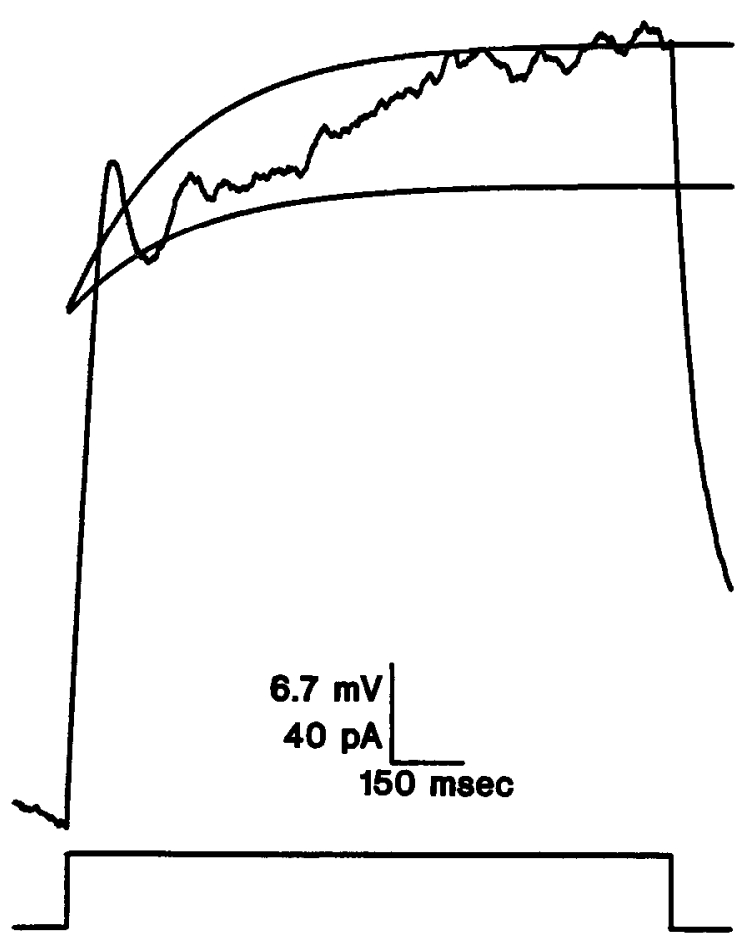

Figure 16. Fitting the slow membrane polarization with the time course of $I_{\mathrm{B}}$. The gradual membrane depolarization measured in Figure $15 D$ is compared with the magnitude and kinetics of $I_{B}$ measured in Figure 14. We used currents with a time constant of $240 \mathrm{msec}$, the time constant for the current at $-30 \mathrm{mV}$. The lower and upper curves represent the voltage due to this current through the chord resistance at the beginning $(0.25 \mathrm{G} \Omega)$ and end $(0.52 \mathrm{G} \Omega)$ of the trace, respectively. It is likely that no other significant conductances contribute to the chord resistance during the inactivation (see text). 
even though the voltage change cannot be fit by a single-exponential function, it can be bracketed using 2 exponentially decaying currents that take into account the change in chord resistance of the cell during the voltage excursion.

Functional significance of $I_{B} . I_{B}$ appears to serve at least 2 important functions. First, when $I_{B}$ is activated rapidly by excitatory currents large enough to elicit spike activity, it acts to shunt the membrane, thereby limiting depolarization to a level of little sodium inactivation, assuring that more than a single spike will be generated. Second, the gradual inactivation of this current with time will limit the number of spikes that a ganglion cell generates by allowing depolarization into the sodium inactivation region. Thus, $I_{B}$ seems (1) to extend the graded range of response in terms of spike number for short periods of up to $200 \mathrm{msec}$ following a large excitatory input and (2) to limit the total number of spikes generated by the cell.

These findings suggest for the first time that the ganglion cell membrane contains voltage-gated currents that act to limit the time course of the spike response. Such modulations have previously been assigned to lateral interactions (Werblin, 1978) or voltage-gated currents (Attwell and Wilson, 1980) in distal regions of the retina. In future work we hope to be able to assign this and other functions to specific classes of ganglion cells.

\section{References}

Adams, P. R., D. A. Brown, and A. Constanti (1982) M-Currents and other potassium currents in bullfrog sympathetic neurones. J. Physiol. (Lond.) 330: 537-572.

Adrian, R. H., W. K. Chandler, and A. L. Hodgkin (1970) Voltage clamp experiments in striated muscle fibres. J. Physiol. (Lond.) 208: 607-644.

Aldrich, R. W., P. A. Getting, and S. H. Thompson (1979) Inactivation of delayed outward current in molluscan neurone somata. J. Physiol. (Lond.) 291: 507-530.

Attwell, D., and M. Wilson (1980) Behaviour of rod network in tiger salamander retina mediated by membrane properties of individual rods. J. Physiol. (Lond.) 389: 287-316.

Barnes, S., and F. Werblin (1986) Gated currents generate single spike activity in amacrine cells of the tiger salamander retina. Proc. Natl. Acad. Sci. USA 83: 1509-1512.

Baylor, D. A., and R. Fettiplace (1979) Synaptic drive and impulse generation in ganglion cclls of turtlc retina. J. Physiol. (Lond.) 288 . 107-127.

Belgum, J. H., D. R. Dvorak, and J. S. McReynolds (1982) Sustained synaptic input to ganglion cells of mudpuppy retina. J. Physiol. (Lond.) 326: $91-108$.

Belgum, J. H., D. R. Dvorak, and J. S. McReynolds (1983) Sustained and transient inhibitory inputs to on-off ganglion cells in the mudpuppy retina. J. Physiol. (Lond.) 340: 599-610.

Cole, K. S., and J. W. Moore (1960) Ionic current measurements in the squid giant axon membrane. J. Gen. Physiol. 44: 123-167.

Connor, J. A., and C. F. Stevens (1971a) Voltage clamp studies of a transient outward membrane current in gastropod neural somata. J. Physiol. (Lond.) 213: 21-30.

Connor, J. A., and C. F. Stevens (1971b) Prediction of repetitive firing bchavior from voltage clamp data on an isolated neurone soma. J. Physiol. (Lond.) 213: 31-53.
Fenwick, E. M., A. Marty, and E. Neher (1982) Sodium and calcium channels in bovine chromaffin cells. J. Physiol. (Lond.) 331: 599635.

Firestein, S., and F. Werblin (1987) Gated currents in isolated olfactory receptor neurons of larval tiger salamander. Proc. Natl. Acad. Sci. USA 84: 6292-6296.

Hamill, O. P., A. Marty, E. Neher, B. Sakmann, and F. J. Sigworth (1981) Improved patch-clamp techniques for high resolution current recording from cells and cell-free membrane patches. Pfluegers Arch. 391: 85-100.

Hermann, A., and A. L. F. Gorman (1981) Effects of 4-aminopyridine on potassium in a molluscan neuron. J. Gen. Physiol. 78: 63-86.

Hodgkin, A. L., and A. F. Huxley (1952a) The components of membrane conductance in the giant axon of Loligo. J. Physiol. (Lond.) 116: 473-496.

Hodgkin, A. L., and A. F. Huxley (1952b) The dual effect of membrane potential on sodium conductance in the giant axon of Loligo. J. Physiol. (Lond.) 116: 497-506.

Kaneko, A., and M. Tachibana (1985) A voltage-clamp analysis of membrane currents in solitary bipolar cells dissociated from Carassius auratus. J. Physiol. (Lond.) 358: 131-152.

Lasater, E. M. (1986) Ionic currents of cultured horizontal cells isolated from the white perch retina. J. Neurophysiol. 55: 499-513.

Lee, K. S., and R. W. Tsien (1982) Reversal of current through calcium channels in dialysed single heart cells. Nature 297: 498-501.

Lipton, S. A., and D. L. Tauck (1987) Voltage-dependent conductances of solitary ganglion cells dissociated from the rat retina. J. Physiol. (Lond.) 385: 361-391.

Lukasiewicz, P. D., and F. S. Werblin (1985) Electrical properties of tiger salamander retinal ganglion cells. Abstr. Soc. Neurosci. 11: 242.

Lukasiewicz, P., and F. S. Werblin (1986) Three different forms of ganglion cell activity mediated by synaptic and voltage gated currents. Invest. Ophthalmol. Vis. Sci. Suppl. 27: 130.

Meech, R. W., and N. B. Standen (1975) Potassium activation in helix asperso neurons under voltage clamp: A component mediated by calcium influx. J. Physiol. (Lond.) 249: 211-239.

Miller, R. F., and R. F. Dacheux (1976) Synaptic organization and ionic basis of on and off in mudpuppy retina. III. A model of ganglion cell receptive field organization based on chloride-free experiments. J. Gen. Physiol. 67: 661-678.

Moore, J. W., M. P. Blaustein, N. C. Anderson, and T. Narahashi (1967) Basis of tetrodotoxin's selectivity in blockage of squid axons. J. Gen. Physiol. 50: 1401-1411.

Schwartz, J. R., and W. Vogel (1971) Potassium inactivation using myelinated nerve fibres of Xenopus laevis. Pfluegers Arch. 330: 6173.

Stewart, W. W. (1978) Functional connections between cells as revealed by a highly fluorescent naphthalimide tracer. Cell 14: 741759.

Thompson, S. H. (1977) Three pharmacologically distinct potassium channels in molluscan neurones. J. Physiol. (Lond.) 265: 465-488.

Weakly, J. N. (1973) The action of cobalt ions on neuromuscular transmission in the frog. J. Physiol. (Lond.) 234: 597-612.

Werblin, F. S. (1977) Regenerative amacrine cell depolarization and formation of on-off ganglion cell response. J. Physiol. (Lond.) 264: 767-785.

Werblin, F. S. (1978) Transmission along and between rods in the tiger salamander retina. J. Physiol. (Lond.) 280: 449-470.

Wollner, D. A., and W. A. Catterall (1986) Localization of sodium channels in axon hillocks and initial segments of retinal ganglion cells. Proc. Natl. Acad. Sci. USA 83: 8424-8428.

Wunk, D. F., and F. S. Werblin (1979) Synaptic inputs to the ganglion cells in the tiger salamander retina. J. Gen. Physiol. 73: 265-286. 